Ltd., of Manchester, and $£ 25,000$ from the Man-made Fibres l'roducers' Committee, acting on behalf of the following producers: British Celanese, Ltd.; British Enka, Ltd.; British Nylon Spinners, Ltd.; Courtaulds, Ltd. ; Harbens, Ltd.; Kirklees, Ltd.; Lansil, Ltd. ; Lustrafil, Ltd.; Nelsons Silk, Ltd.; and North British Rayon, Ltd.

Very-high-frequency Broadcasting in Great Britain

THe first stage of the scheme by the B.B.C. to introduce sound broadcasting on very high frequencies, as envisaged in the second report of the Television Advisory Committee (see Nature, February 13, p. 297), has now received government approval, and work is proceeding in setting up the nine stations that will each send out the home, light and third programmes on frequencies in the range 88-95 Mc./s., using frequency-modulation. The stations will be in Wrotham (Kent), Pontop Pike (near Newcastle), Divis (Northern Ireland), Meldrum (near Aberdeen), Norwich, South Devon, Sutton Coldfield (near Birmingham), West Wales and Holme Moss (near Huddersfield), and will radiate $60 \mathrm{~kW}$., except Wrotham, Norwich, Sutton Coldfield and Holme Moss, which will radiate $120 \mathrm{~kW}$. The network is intended primarily to reinforce, and not supplant, the long-wave and medium-wave services already in existence and should make it possible to receive the three programmos free from interference in many areas where reception on medium wave-lengths is spoiled by interference and fading, especially after dark during the winter months. At Wrotham there are already two transmitters, which have been carrying an experimental service since 1950 ; a third transmitter will be installed, and the station will be brought into regular service in May next year. The other eight stations will be completed during the following eighteen months; they will be at the same sites as television stations, and the same masts will be used as for the television transmissions. The site for West Wales has not yet beon settled. The radio industry in Britain is ready to produce receivers designed for very-high-frequency reception and adaptors for use with existing receivers, and these will become available in the various areas in time for the opening of the respective stations.

\section{Scenes of Red Indian Life in the 1830's}

During the 1830 's, George Catlin, a self-trained artist, painted more than five hundred pictures of Red Indians and Western scenes in the United States, and the majority of these are now lodged in the Smithsonian Institution, Washington, D.C. Through the Information Section of the American Embassy in London, a selection of twenty-seven paintings are being shown in the Whitechapel Art Gallery, London, and this exhibition will continue until August 8 (admission free; daily 11 a.m.-6 p.m.; Sundays, 2-4 p.m. ; closed Mondays). In conjunction with the Catlin paintings, there is also the Combined Societies Exhibition of International Photography, 1954. Catlin took great trouble over his work and was well aware of the importance of accuracy, so that his paintings are authoritative records of the life and appearance of Red Indians a hundred and twenty ycars ago. The paintings at the Whitochapel Art Gallery cover mainly his journeys in the Santa FeFort Gibson area (lying within New Mexico, Texas and Oklahoma) during 1834 and in the Fort Clark-Fort Pierre area (lying within North and South Dakota) during 1832, and depict respectively Mandans and
Sioux. Though perhaps the art is not of a first-rate order, the paintings (which are in oil on canvas) are nevertheless very pleasing by the great dignity of the sitters conveyed in the posed portraits, and by the free, lively, almost Impressionist, style of some of the landscapes and broad scenes of village life; the colours are agreeably subdued. It is interesting to note that, after touring the United States in 1838-39, the majority of Catlin's paintings were housed during the 1840 's in London at his gallery in 6 Waterloo Place, and his account of his exploits were published in England in a two-volume work entitled "Letters and Notes on the Manners,' Customs, and Conditions of the North American Indians" by Geo. Catlin, "Written during Eight Years' Travel amongst the Wildest Tribes of Indians in North America, in $1832,33,34,35,36,37,38$, and 39 " ; a copy of the third edition of this work, dated 1842 and published by Tilt and Bogue, of Fleet Street, London, is on show at Whitechapel and contains four hundred line engravings which Catlin prepared from his original paintings.

Thirty-five Catlin paintings have been acquired by the Chicago Natural History Museum, and these are reproduced in a little book by George I. Quimby, curator at the Museum, entitled "Indians of the Western Frontier : Paintings of George Catlin". Red Indians in various kinds of costimes are depicted, and there is also an interior, a hunting scene and two or three drawings of bison.

\section{Scientia Electrica: New Swiss Journal of Applied Electricity}

IN the past thirty years the scientific principles used in electrical engineering have become more complicated and recondite, and the volume of scientific papers has correspondingly grown. In Great Britain the Institution of Electrical Engineers has found a place for all types of papers concerned with electrical science, except for a small number published by the Royal Society, Physical Society, Institute of Physics and elsewhere. The position is not so satisfactory abroad, and a new journal, Scientia Electrica : Moderne Probleme der theoretischen und angewandten Elektrotechnit (Band 1, Heft 1, October 1953, pp. 40, 4 Fr.; Heft 2, January 1954, pp. 42, 4 Fr.; Heft 3, June 1954, pp. 46, 4.80 Fr. Zurich : S. Hirzel Verlag), edited by Prof. Max Strutt, has been started in Switzerland to cover current advances and problems in the scientific aspects of the theory and practice of electric technology ; the contents of the first three numbers are contributed from colloquia given at the 'Technical High School, Zurich, by leading experts. It is intended to publish submitted articles of suitable merit within the given terms of reference. The articles so far published contain reviews of recent progress together with some original work of the authors. The subjects chosen are both interesting and important, such as transistor amplifiers, fine transfer in contacts, corona loss in high-voltage transmission, absolute voltage measurement, new insulating materials, and backfires in mercury are rectifiers. Presumably, submitted articles will often be of narrower scope and confined to original work. If so, thoso concerned in electrical science will certainly have to take note of this new journal. Even should the articles remain somewhat of a review type, the important work on applied electricity in Switzerland and the standing of the journal's sponsors are such as to ensure the standard and usefulness of its contents. 